Anderson ARAUJO

\title{
POUNDIANS ON THE TRAIL OF EL CID*
}

УДК $82-991$

DOI 10.22455/2541-7894-2019-7-498-504

\author{
Андерсон АРАУЖО \\ ПАУНДОВЕДЫ В ИСПАНИИ: \\ ПУТЕШЕСТВИЕ ПО СЛЕДАМ СИДА
}

(C) 2019 Anderson Araujo (PhD, Associate Professor, University of British Columbia, Canada) anderson.araujo@ubc.ca

(c) 2019 Андерсон Араужо (PhD, доцент, Университет Британской Колумбии, Канада) anderson.araujo@ubc.ca

No EPIC is complete without a post-conference excursion. It has become such a mainstay of the biannual Ezra Pound International Conference that it's easy to forget how rare an event it is among academic gatherings. Perhaps above all, the excursion is a testament to the collegial atmosphere of this community of Pound scholars, a community that is as international as it is intergenerational. After several days of talks, panels, poetry readings, concerts, dinners, and late-night impromptu gatherings it is a wondrous thing that no one ever seems to grow tired of each other. Indeed, we all seem to want to more of it - hence the excursion! It should be said that none of this would be possible without the extraordinary commitment of the organizers. The 2019 excursion was no different, and any account of the trip worth its salt must acknowledge the hands-on management and leadership of Viorica Patea and John Gery. The EPIC in Salamanca was all the more special, as this was the first time it was held in Spain, a seminal country for Pound and an indelible experience for all of us. Burgos, the historic old capital of the northern kingdom of Castile, proved to be an ideal locale for our first stop.

* I owe a debt of gratitude to John Gery for several details featured in this account. The report also appears in Make It New. 
Dragging my luggage laden with books across Salamanca's nearly deserted streets on a bright Sunday morning I was soon soaked in sweat. The clickety-clack of plastic wheels and cooing pigeons echoed on the sandstone buildings of this charming university town. I couldn't help but feel a bit wistful at this tail end of my two-week stay. My ennui was brief, however, as I spied an excited group of Poundians milling about Plaza Fonseca, our point of departure. We were soon off to the "dream city of Old Castile," as Pound described it in 1906. The tour bus chugged along to the lively hum of chatter, laughter, and the odd snort from a sleeper jolted awake in the roughly two-hour-plus drive northeastward.

As we entered Burgos, Viorica's voice piped through the PA system with historical facts about the city and its fabled landmarks. A place I'd long imagined as a bucolic town is anything but. Yet even amidst the hubbub of this bustling, modern city it's not hard to see why in the early days of the Spanish Civil War in 1936 Franco chose to proclaim himself "jefe del Estado" here, at the Capitanía Palace, now a military museum. After all, the building is just a stone's throw away from Burgos Cathedral, the resting place of none other than Spain's legendary warrior, El Cid Campeador. Few, if any, traces of Franco's legacy remain, but the shadow of the Christian Castilian knight he imagined himself to embody shows no signs of vanishing. The bus looped around Plaza Mío Cid, featuring the equestrian statue of the eponymous hero, and crossed one of the many bridges over the Arlanzón river in the heart of the historic district. At last, we pulled up to Hotel Corona de Castilla, on Calle Madrid, just a few minutes' walk away from the main attractions. As we spilled out of the bus and made a bee line for the entrance the afternoon heat made the thought of a siesta virtually irresistible. The $36 \mathrm{C} / 97 \mathrm{~F}$ readout on a nearby street thermometer made a mockery of this, one of Spain's coldest provincial capitals. Following lunch and a de rigueur shuteye, reenergized Poundians sauntered over to Burgos Cathedral to begin our guided tour of this UNESCO World Heritage Site. It is no wonder Pound once dubbed Paris's Notre Dame "crude" by comparison. The stunning Gothic architecture of Our Lady of Burgos dwarfs everything else around it. And yet, as Pound noted, "it is a white cob-web, delicate as no picture seems to show it." Prior to the tour, as we stood just outside the cathedral's Puerta Sarmental, John Gery read to us in his inimitable way Pound's thoughts on the picaresque adventures of the Cid and his impressions of the "web of spun stone" we were about to enter. One of the promised highlights of the 
excursion, the tour exceeded expectations. A longtime cynic about curated experiences, I was impressed by the selective array of information our guide chose to regale us with, skipping the typically rambling (and, sometimes, fabricated) tidbits of infotainment that so often taints such visits. So magnificent is the building that the austere burial place of the Cid and his wife, Doña Jimena, seemed almost like an afterthought by the time we finally gathered around the red velvet stanchion rope protecting it. Seemingly hovering in midair above it all, the Renaissance lantern vaulting shone in exquisite glory. As we stood looking at the choir, John resumed reading Pound's account. Unlike the bulky "black mass" of the Seville and Toledo cathedral choirs and that of the mosque-cathedral of Cordoba, Burgos's "choir is of light, cleanlined iron-work, and obstructs nothing but the footsteps of travelers and children from the inner place of sanctuary." Near the end of the tour we also came upon the Cid's safe, the "trunk," as John read to us from Canto III, that he left "with Raquel and Vidas, / That big box of sand, with the pawn-brokers, to get pay for his menie." As we exited the cathedral and crossed under the emblematic Arco de Santa María, the main gate leading into the city, a torrential downpour sent everyone scurrying for cover. It also put the kibosh on our planned close-up visit to the Cid's statue we'd glimpsed from aboard the bus earlier in the day. With the tour effectively over, several of us took no time in patronizing one of the several tourist-trap bars along the picturesque Paseo Marceliano. The day still had a surprise in store for those of us who lingered around the old town center. Finding a restaurant proved to be more difficult than we'd anticipated, as the crowds began to throng for the start of the week-long Feast of St. Peter and St. Paul, a venerable tradition affectionately known here as "Sampedros." After dinner, our entourage began the trek back to the hotel only to find ourselves caught in a massive celebration. The boozy roar of burgalese youth mixed with the high-pitched yells of children, chattering families, and bemused visitors. The mood was decidedly exuberant. Turning into Plaza Rey San Fernando, we came upon revellers clad in identical striped shirts, all of them singing at the top of their lungs the iconic anti-fascist tune, "Bella Ciao." Given the rise of reactionary politics rearing its ugly head in Europe and elsewhere, this was a joyously hopeful spectacle. With the mazy medieval streets cordoned off at unpredictable points, we had no choice but to follow the only path still accessible to the Santa María bridge, the shortest route back to the hotel. But, as we soon discovered, the bridge itself was blocked. "For the fireworks!" a policeman belted out above the noise. Walking further along the riverbank we found a clearing among the spectators waiting for the night's much-awaited climax to get under way. 
Once the first explosion shook the sky above us the ensuing upward cascade never seemed to stop. Burgos must set aside a goodly chunk of its annual budget for this. What a show! With pyrotechnic orbs still dancing in our eyes well after the last streamers had sputtered out, we cut our way through pungent clouds of gunpowder and the dispersing crowd back to the hotel.

A hearty breakfast buffet greeted us in the mezzanine the following morning. The sun was already high in the midsummer sky by the time we left Burgos. We barely had a chance to settle into our seats when the bus pulled up to the sprawling grounds of San Pedro de Cardeña Monastery, just a few miles outside the city. This is where the Cid found refuge and left his wife and two daughters, María and Cristina, before going into exile. A resident Cistercian monk gave us an in-depth guided tour. Aside from the tower and cloister, little is left of the original Romanesque monastery founded by the Benedictines in 899 . The oft-plundered building has seen much turmoil over the centuries. During the Spanish Civil War, Franco even used it as an impromptu concentration camp. The Capilla del Cid (the Cid's Chapel) still contains the $12^{\text {th }}$-century sarcophagus that once housed his and Jimena's remains. As the legend goes, the Cid's horse, Bavieca, was buried just outside the abbey church, in a spot marked by a monolith. John read a

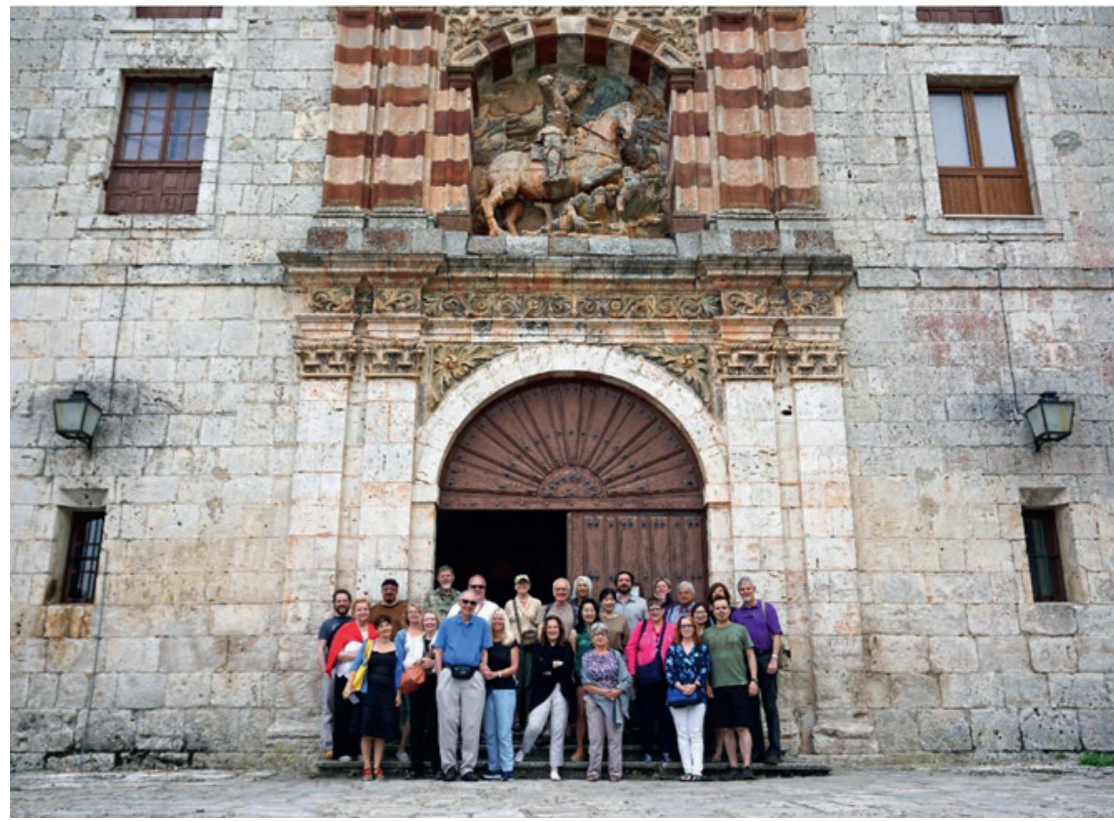


short paragraph on the beloved white stallion and, following a quick visit to the hole-in-the-wall souvenir shop, off we went to our next destination.

After travelling southeastward for nearly three hours we arrived in Medinaceli, a village in the province of Soria with a history that spans at least two millennia. Its Celtiberian-Moorish legacy is evident in its name (literally "hill" "town" or, more fancifully, "celestial city"). Even from afar one can make out the contours of its striking Roman Arch, the gateway to this strategically important settlement since the $1^{\text {st }}$ century CE. Medinaceli is also located along the Camino del Cid. Immortalized in the epic Poem of El $\mathrm{Cid}$, the hero's famous route crosses Spain from Burgos to the Mediterranean coast. Truth be told, however, little of that mattered as the hunger pangs hit us hard. Luckily, a scrumptious menu awaited us at the quaint La Cerámica Restaurant, featuring typical Spanish dishes as well as local Sorian delicacies. With bodies and spirits revived, we took a short stroll to the nearby Plaza Obispo Minguela. Here, for nearly half a century has stood the stone plaque commemorating Pound. "¿Cantan aún los gallos al amanecer en Medinaceli?" ("Do the roosters still crow at dawn in Medinaceli?"), reads the epigraph. For non-Poundians, the query must seem beyond cryptic. Yet, to those of us standing there, as John's voice once again brought the Cantos alive in situ, it held an intimate, if somewhat whimsical, meaning. Surely, I thought, we all share the same thrill of knowing the backstory, like a benign

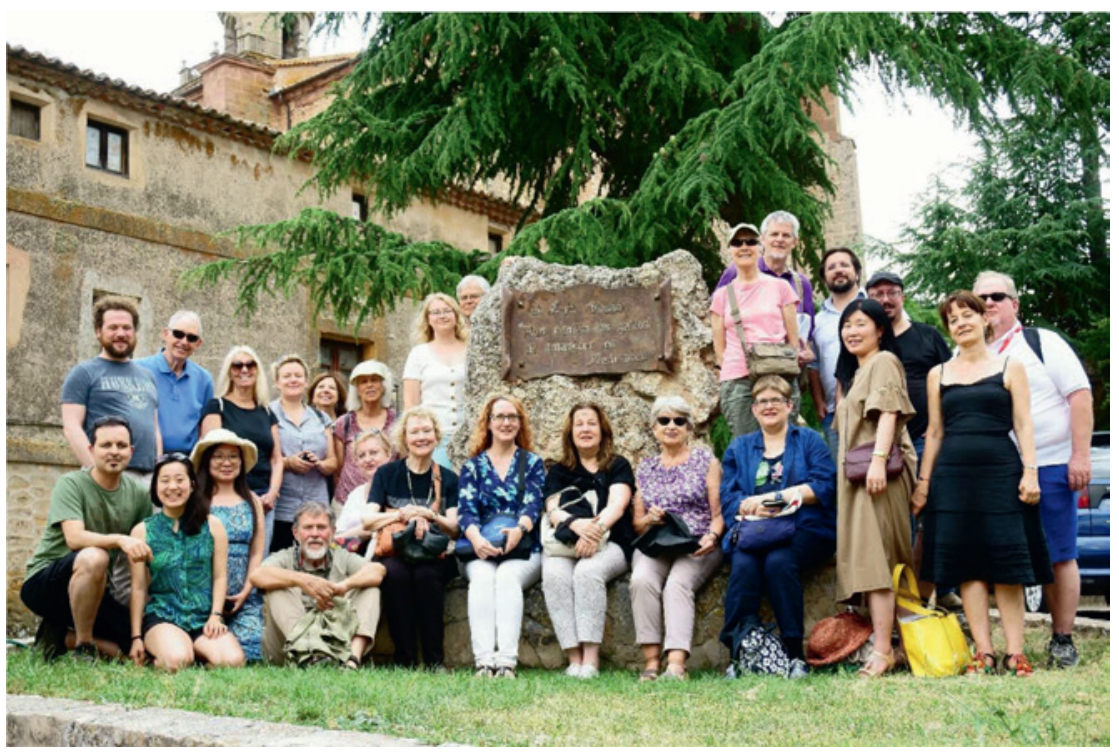


cabal or holders of some secret language. Gathering everyone in front of the plaque, I mounted my camera precariously on my backpack, set the timer, and ran to the edge of the group. The idea for this makeshift tripod, which had worked so well at the monastery, would soon prove to be disastrous here. The five-photo sequence I'd programmed shook the camera just enough to send it crashing onto the stone road beneath it, breaking the lens mechanism and rendering the whole apparatus useless. Before its untimely plunge, however, a final shot captured a perfect memento of our visit. A silver lining, if ever there was one. With a storm looming in the offing, there was little time to bemoan the loss. We loaded up the bus and wended our way downhill toward our final destination.

Driving into the Spanish capital along the main "paseos" ("avenues") Paseo de la Castellana, Paseo de Recoletos, and Paseo del Prado - opens a smorgasbord of cultural landmarks. En route to the Hotel Ganivet, where the group would stay, we passed the National Library of Spain, Cibeles Palace, the Royal Botanical Gardens, as well as the most important museums, including Reina Sofía, Thyssen-Bornemisza, and the Prado. Just a stone's throw away from Puerta de Toledo, the hotel is also within easy reach of many of Madrid's main attractions. The next morning, the Pound walking tour kicked off from the Ganivet at 9:30. By the time I caught up with the group from my digs uptown, they were in front of the house on Calle de Arrieta, 8, near the Royal Library, where Pound stayed for a few weeks in 1906 to study the role of the gracioso in the plays of Lope de Vega. Once John finished reading excerpts from Pound's letters of this period, we looped around the Royal Theater and the gardens of the Royal Palace. A few minutes later, we turned into the bustling Calle Mayor and almost immediately found ourselves in front of the monument commemorating the victims of the failed assassination attempt against King Alfonso XIII and Victoria Eugenie of Battenberg, on their wedding day, no less, on May 31, 1906. We then walked for another ten minutes to Puerta del Sol, the very heart of Madrid, where on that fateful day Pound heard the explosion that killed dozens and injured scores. A quick stop for an espresso in one of the cafés in the nearby Plaza de Santa Ana gave us a chance to catch our breath and take in the sights and sounds of midday Madrid. A five-minute stroll afterwards led us to Calle Cervantes for a guided visit of the restored $17^{\text {th }}$-century museum-house of Lope de Vega, where he wrote some of his most acclaimed works. There must be some kind of cosmic irony in the fact that Pound's favourite Spanish playwright and the author of Don Quixote - the Golden Age's greatest 
rivals - lived and died so close to each other (Casa de Cervantes is just a few houses away). After lunch, the group met at the Prado Museum for the artistic apex of the excursion. During the visit, the guide focused above all on the Spanish collections: El Greco, Velázquez, and Goya. Poundians were particularly moved by the Goya rooms. Following the official tour and a coffee break, John returned with a handful of people to the Velázquez rooms to soak up the iconic masterpieces, especially The Surrender of Breda and Las Meninas. A more fitting finale to the excursion is hard to imagine, with Canto 80 undoubtedly riffing in everyone's minds - "Breda, the Virgin, Los Boracchos," and "Las Hilanderas," even if Las Meninas no longer hangs by itself in a room, as it once did when Pound saw it.

It goes without saying that Spain won't soon be forgotten. Nor am I alone in thinking, like the Infanta Maria Luisa of Canto 44, that many of us would be "in a hurry to get [back] to Spain," if given the chance. But for now, so many memories will do. And apropos of memories, it might be worth closing with an epilogue to my earlier mishap with the camera lens. I did find a repair shop in Madrid, which brought the mechanism back to perfection just in time for my trip home and, one dares hope, the next EPIC excursion. 